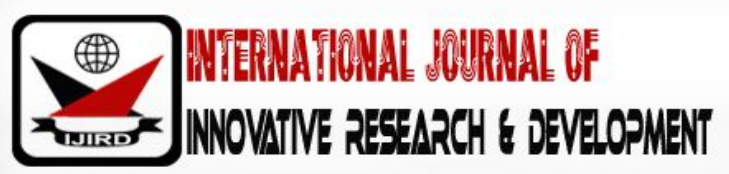

ISSN 2278 - 0211 (Online)

\section{Factors Influencing Low Performance of Pupils in BDT Sewing at a Junior High School in Efutu Municipality}

\author{
Rosemary Quarcoo \\ Lecturer, University Of Education Winneba, Ghana
}

\begin{abstract}
:
The study design was a descriptive survey which sought to get answers to the following research questions: What factors accounts for the low performance of pupils in BDT sewing at a particular JHS in Efutu Municipality, Ghana?' How can pupil's interest in BDT (Sewing) be enhanced? A purposive sampling technique was used to get a sample size of 100 respondents. A questionnaire was used to collect data and descriptive statistical tools were used to analyze the close ended questions and a thematic approach was adopted for analyzing the open ended questions. Majority of the respondents agreed that, factors influencing the low performance of pupils in BDT (Sewing) include, students consider it unimportant, teaching and learning of BDT sewing is boring, many topics in BDT sewing are difficult. The provision of teaching and learning resources, the effective use of teaching learning resources and strategies, organization of fieldtrips, allocation of more time to BDT ( Home Economics) were suggested as ways of enhancing students' interest in BDT(Sewing).
\end{abstract}

Keywords: Factors, low performance, pupils, basic design and technology (BDT), sewing

\section{Introduction}

Education is accepted as the process by which individuals acquire knowledge, skills and attitudes which enable them to develop their faculties in full. It is universally accepted that one of the benefits of good education is to enable individuals contribute to development and improvement in the quality of life for themselves, their communities and the nation as a whole.

Decroly (2009) further explained that education is a key to the development of every individual, the society and the nation as a whole. He added that the primary aim of education is to enable the child to be resourceful in the solution of the problems connected with his own needs. Due to the importance of education, Ghana government has attached a lot of seriousness to the education sector in order to reap all the benefitsassociated with it. For this reason the main aim of education in Ghana is the goals of education in Ghana is to provide relevant and quality education for all Ghanaians especially the disadvantaged to enable them acquire skills which will make them functionally literate and productive to facilitate poverty alleviation and promote the rapid socio-economic growth of the country.(Ministry of Education,2010).

Consequently, Vocational and Technical education has been emphasized by all the educational reforms in Ghana. Notable amongst them is theJophus Anamuah-Mensah reforms which placed high premium on technical/vocational education and training and abilities (Ministry of Education, 2002). For this reason, Home Economics has been included in the educational curriculum at all levels of education in Ghana.

At the Junior High School level, it is part of the Basic Design and Technology. Basic Design and Technology is one of the elective subject designed for Junior High Schools in the 2007 Educational Reform. It is a subject that combines the elements of the former courses in Pre-Technical Skills and Pre-Vocational Skills into one subject. By combining Pre-Technical Skills and Pre-Vocational Skills, it is intended that pupils will learn the processes of problem identification, and then use design techniques such as drawing, free-hand sketching and colour work to design a product, and go on to select appropriate tools and materials to make a product or artifact, (GES, 2007). It further emphasizes that Basic Design and Technology adopts the design principles and processes in Pre-Technical Skills and Pre-Vocational Skills and teaches the application of these principles and processes in various aspects of the three vocational options: Pre-Technical Skills, Home Economics and Visual Arts. In this direction, the subject is intended to create individuals who are versatile and creative and who are capable of combining and using variety of knowledge and skills in product development. The development of such young people is crucial in determining the extent to which the country could compete with others in the production of goods and services. 
BDT is a practical subject and learning required is best achieved through practical application of skills learnt by learners. Hence, the profile dimensions required for the subject and their respective weight have 30\% for knowledge and understanding and 70\% for application of knowledge (Skills) (Ministry of Education MOE, 2007).

Daniels and Hobson (1985) stated that Home Economics teacher needs both theoretical and practical resources when preparing for the classroom and most especially in clothing and textiles (sewing) also Blankenship and Moerchern (1979) mentioned that, teaching and learning materials support activities that have been planned to help students achieve objective: Kay (1971: 37) also says "teaching aids are things which are intended to help the teacher to teach more effectively or better still, which enable the pupils to learn more readily". By selecting and using instructional materials properly, one can motivate and sustain the interest of students to clarify information, present new idea, stimulate discussion, summarize what have been learned and provide experience which encourages skill acquisition. (Hall and Paolucci, 1970). Talabi (2006) further explained that, instructional materials should be selected as a means to aid learning and never as an end in itself. In a nutshell,teaching and learning materials when used effectively will help to clarify and illustrate concepts making abstract ideas more concrete thereby aidingunderstanding and sustaining interest of concept learnt.

The Home economics aspect consists of Food and Nutrition (Catering) and sewing. The rationaleisto expose learnersatthe basic level of education to arrange of practical activities in the vocation afield. This will give learners the opportunity to either branch into vocational, technical or general field of education (Anamuah-Mensah,2004; Akyeampong, 2002).

In order to achieve these aims, the teacher's role is very important. The teaching methods used are very important. According to Annoh (1997), one of the signs of good teaching is the use of suitable and effective teaching methods and appropriate teaching learning materials. He added that the principles the teacher must observe with regard to methodology are that; teacher must vary his teaching methods by which ideas and skills are presented. In practical lessons like Home Economics (Sewing), the use of demonstration, project method of teaching, information technology method, discussion, observation methods of teaching etc. are very appropriate for the effective teaching and learning of Sewing.

A growing country like Ghana needs people with requisite practical skills and skilled labour to grow and develop. This was emphasized by Budu-Smith, 2005 that, without skilled technical and vocational manpower produced by educational institutions for industry, commerce and agriculture and ultimately national development would virtually ground to a halt.Vocational and Technical education should therefore be given the necessary attention in order to reap the optimum benefits of this aspect of education.

In spite of the enormous benefits of vocational education to the individual, the family, community and the nation as a whole, the Home Economics aspect of BDT especially the sewing option which according to Arubayi (2003) aims at helping learners acquire knowledge, skills and techniques for meeting personal and societal clothing needs has been taken for granted hence this study.Student's attitude to sewing as a course is very bad and this affects their performance.

There has been a prevalent report about a Junior High School in the Efutu Municipality in Ghana by students' interns about the pupil's poor performance in BDT (sewing) and their poor attitude to class attendance. In order to ascertain this, a pre-data collection exercise was done. The pupils in this particular school were observed and scored. The results are shownin

Table 1 below.

\begin{tabular}{|c|c|c|c|c|c|c|}
\hline Attribute & $\begin{array}{c}\text { Very } \\
\text { Good } \\
\mathbf{1 0 - 8} \\
\end{array}$ & $\begin{array}{c}\text { Good } \\
7-6\end{array}$ & $\begin{array}{l}\text { Fair } \\
5-4\end{array}$ & $\begin{array}{c}\text { Poor } \\
3-2\end{array}$ & $\begin{array}{c}\text { Very } \\
\text { Poor } \\
0-1 \\
\end{array}$ & $\begin{array}{c}\text { Total } \\
10\end{array}$ \\
\hline $\begin{array}{l}\text { 1. Handling and using of basic sewing tools and equipment } \\
\text { (pair of scissors, pins, tape measures) }\end{array}$ & $8 \%(8)$ & $10 \%(10)$ & $20 \%(20)$ & $42 \%(42)$ & $20 \%(20)$ & $100 \%(100)$ \\
\hline 2. Threading the sewing machine & $7 \%$ & $8 \%$ & $23 \%$ & $35 \%$ & $27 \%$ & $100 \%$ \\
\hline 3. Skills in sewing with sewing machine and cut out fabric & $5 \%$ & $7 \%$ & $20 \%$ & $40 \%$ & $28 \%$ & $100 \%$ \\
\hline 4. Skills in making different types of stitches & $5 \%$ & $10 \%$ & $20 \%$ & $30 \%$ & $35 \%$ & $100 \%$ \\
\hline 5. Skills in patching articles & $10 \%$ & $15 \%$ & $25 \%$ & $30 \%$ & $20 \%$ & $100 \%$ \\
\hline 6. Skills in fixing, opening and fastening e.g. button & $9 \%$ & $11 \%$ & $20 \%$ & $38 \%$ & $22 \%$ & $100 \%$ \\
\hline
\end{tabular}

Table 1: Performance Assessment of JHS Pupils in BDT Sewing Before Data Collection.

Source: Data Collected From the Field

From table 1, it was observed that only 18 pupils out of 100 pupils constituting $18 \%$ were able to handle and use basic sewing tools and equipment (pair of scissors, pins and tape measures),17\% were able to thread the sewing machine, $12 \%$ 
were able to cut and sew with the sewing machine, $15 \%$ out of the pupils were very good at making different types of stitches, $25 \%$ could patch articles, $19 \%$ could fix buttons based on their classes showing a low performance show of student.

Determinants of students' academic performance have received significant attention in the education literature. Students' performance is generally viewed as a product of socio-economic, psychological and environment factors. The factors are expected to vary from one country to another and from place to place. A myriad of factors have been seen to have an impact on students' performance among these,Schneider, Gruman \& Coutts (2012) have found teacher and student attitudes to be the most outstanding factor.

Attitude and perception requires an amount of action on the part of the perceiver and the process usually works to guide attitude of students and thereby stimulate the interest of the student. Aiken (2002) stated that, positive attitudes towards a subject motivate students to spend more timestudying and thinking about it.

\subsection{Statement of the Problem}

Several student interns complain of the poor performance of students in BDT sewing at a particular Junior High School (JHS) in the Winneba Municipality. It has been observed and reported by intern students that, pupils in this particular school were not able to score good grades in both exams and exercises. Aside that their participation during class hours was always poor and their practical works were inappropriate.

Through observation the interns realized that some of the factors that may be influencing the low performance are, Attitude of some teachers, inadequate facilities (Tools and equipment), perception of pupils that BDT sewing is difficult, perception of male and female students regarding their career aspirations etc.

As a supervisor of these interns, and a Clothing and Textiles educationist, I have taken it upon myself to investigate the factors influencinglow performance and interest of pupils in BDT sewing a subject that has the potential of making an individual an independent and whole human being and at the same time, leaving the nation as a developed nation.

\subsection{Purpose of the Study}

The purpose of the study is to identify factors influencing low performance of students in BDT sewing at a Junior High school in Winneba.

\subsection{Specific Objective}

- To identify the factors responsible for low performance of pupilsin BDT sewing in this particular JHS in Efutu Municipality.

- To determine ways of developing pupils interest in BDT sewing.

\subsection{Research Questions}

- What factors accounts for the low performance of pupils in BDT sewing in a JHS at Efutu Municipality?

- How can pupils' interest in BDT (Sewing) be enhanced?

\subsection{Significance of the Study}

The result of the study will benefit the heads of Junior High Schools, teachers, the school and the parents of the pupils in that, all these stakeholders of education can now find a lasting solution to some of the factors affecting the low performance and interest of pupils in BDT (Sewing) in order toget the maximum benefits that this subject offers. It will also add to literature.

\subsection{Delimitations}

The study was delimited to only one Junior High School in Efutu Municipality due to the peculiarity and persistency of this problem to this particular school.

\section{Methodology}

\subsection{Research Design}

The research design for this study is descriptive survey.

\subsubsection{Sample Size and Sampling Technique}

One hundred (100) pupils from Basic 7-9 were purposively sampled out of the school population of Five Hundred and Fifty (275) pupils because, they offer BDT (Home Economics). Seventy Five (75) students in first year (B7) because, it is a compulsory subject at this stage, fifteen in B8 and ten (10) in B(9).

\subsection{Data Collection Procedure}

The information for the study was obtained from two main sources namely, primary and secondary sources. The primary data was obtained through the use of observation and questionnaire. The secondary data on the other hand was acquired from publications, journals and books. 


\subsection{Data Collection Instruments}

Questionnaire was used for data collection. The questionnaire was made up of two parts. The first part elicited responses on research question 1 'What factors accounts for the low performance of pupils in BDT sewing?' and these were made up of close ended questions designed on a four point Likert scale ranging from Strongly Agree(SA), Agree (A), Disagree(D) and Strongly Disagree (SA). The second part was made up of open ended questions which elicited responses from students to answer the second research question 'How can pupil's interest in BDT (Sewing) be enhanced?'

\subsection{Data Analysis}

Research question one(1) was analyzed and presented using simple frequency distribution and percentage table and for Research question two (2) a qualitative approach was used for the analysis where the responses were put into themes for analysis purposes.

\section{Results and discussion}

\subsection{Research Question 1}

\begin{tabular}{|c|c|c|c|c|c|}
\hline Attribute & Sa & A & D & Sd & Total \\
\hline $\begin{array}{c}\text { 1.The study of B.D.T is } \\
\text { considered not important }\end{array}$ & $36(36 \%)$ & $30(34 \%)$ & $20(20 \%)$ & $10(10 \%)$ & $100(100 \%)$ \\
\hline $\begin{array}{c}\text { 2. The teaching and learning of } \\
\text { B.D.T sewing is boring. }\end{array}$ & $40(40 \%)$ & $25(25 \%)$ & $25(25 \%)$ & $10(10 \%)$ & $100(100$ \\
\hline $\begin{array}{c}\text { 3. The confident level of } \\
\text { learners in B.D.T affects their } \\
\text { performance in the subject }\end{array}$ & $44(44 \%)$ & $36(36 \%)$ & $12(12 \%)$ & $8(8 \%)$ & $100(100 \%$ \\
\hline $\begin{array}{c}\text { 4. Money spent on B.D.T project } \\
\text { work is too much }\end{array}$ & $35(35 \%)$ & $37(37 \%)$ & $8(8 \%)$ & $20(20 \%)$ & $100(100 \%$ \\
\hline $\begin{array}{c}\text { 5. Many of the } \\
\text { Topicsin BDT } \\
\text { sewing is difficult. }\end{array}$ & $40(40 \%)$ & $30(30 \%)$ & $20(20 \%)$ & $10(10 \%)$ & $100(100 \%)$ \\
\hline $\begin{array}{c}\text { 6. Teachers pay more attention } \\
\text { to only those who have interest } \\
\text { in the subject. }\end{array}$ & $22(20 \%)$ & $50(50 \%)$ & $15(17 \%)$ & $13(13 \%)$ & $100(100 \%)$ \\
\hline
\end{tabular}

Table 2: What Factors Accounts for the Low Performance of Pupils in BDT Sewing?

Keys: $\mathrm{SA}=$ Strongly Agree, $\mathrm{A}=$ Agree, $\mathrm{D}=$ Disagree and $\mathrm{SD}=$ Strongly Disagree.

From table 2, it was found out that 70\% of the pupils agreed that the study of BDT is not important and 30\% however disagreed to this statement. This shows that many of them do not consider BDT as an important subject. Students and the society in which they come for are very ignorant of the benefits for studying Sewing. Most people do not know that, there are over 44 career opportunities to an individual after studying Sewing (Forster, 2014). Because the society is not aware of the benefits of Sewing as a subject, it has been neglected by stakeholders in education and even some Home Economics teachers therefore this area has seen less improvement as noted by Fomadi, (2008). Ignorant people even laugh at the few students who have interest in the subject and are even considered as less endowed academic students while this area is one of the best manufacturing sectors for countries like Italy (www.nationsencyclopedia.com).

$65 \%$ and $80 \%$ of the respondents were of the view that, BDT (Sewing) was boringand confident level of learners in B.D.T affects their performance respectively. For a course or a subject to look attractive and interesting to students, much of it depends of the teacher quality. Asare and Nti (2014), mentioned that, in an era where quality education is a concern for education-focused international organizations and dominates national debates, teacher quality must equally be a priority. A good teacher knows how to go about teaching the most difficult subject in order to make it attractive to the students.According to Annoh (1997) one of the signs of good teaching is the use of suitable and effective teaching methods and appropriate teaching learning materials. He added that the principles the teacher must observe with regard to methodology are that; the teacher must vary his teaching methods by which ideas and skills are presented. This reduces monotony and boredom when a skillful teacher uses several methods to teach or impact knowledge. And also methods of teaching should be related to the stages of growth and development of learners. Sewing as a practical course should have been an interesting course when a good teacher handles it. Students should be helped to understand the basic concept and conceptual relationship that serve as tool in the intelligent ordering of new data or the use of new information. Motivation is the very heart of the teaching and learning process. It energizes and accelerates the behavior of the learner and if students are helped, to grasp the concept taught in sewing, pupils will gain the confidence that, they have good knowledge in sewing and this will boost their 
performance as they indicated.Aiken (2002) stated that,positive attitudes towards a subject motivate students to spend more time studying and thinking about it.

Table 2 also shows that, on the issue of acquisition of resources for the Sewing course, $72 \%$ of the pupils agreed that money spent on B.D.T project works is too much. Therefore most of them were unable to get these resources in order to be part of the class. This hinders their performance.

If students could get help on the acquisition of these teaching learning resources, it will help them participate in class thereby improving performance of the students. According to Chavkin (1993), research has shown that one of the most promising ways to increase students' achievement is to involve their families. Family Impacts on Education Walberg (1984) found that family participation in education was twice as predictive of academic learning as family socioeconomic status.

Most of the pupils (70\%) agree that, many of the topics in BDT (Sewing) are difficult and 72\% also agreed that, teachers pay more attention to only those who have interest in the subject than the others. Students said they find it difficult understanding some of the concepts (topics) in BDT(Sewing). Bruner (1963) stresses that the structure of a subject rather that the factual or descriptive content of it is the key to the encouragement of further learning. The teacher again plays a major role here. According to Asare (2009), the real threat to learning is how teaching is done and suggested that teachers must be taught to engage learners in such a way that would make the learners own and make sense of activities to promote learning.According to Ovens (1992) cited by Mankoe(2002) motivation is made up of all those inner striving conditions described as wishes desires, etc. it is an inner state that activate or moves individuals. If Sewing teachers can motivate their students at this level of learning, Clothing and Textile courses at the higher levels of education would not suffer the deficits they are suffering now.

\subsection{Research Question 2: How Can Pupils' Interest In BDT (Sewing) Be Enhanced?}

Respondents are of the views that, the following can help enhance students' interest in BDT (Sewing).

- $\quad$ Provision of teaching and learning resources by the government and school authorities,

- $\quad$ Ability of parents to buy needed material for them,

- $\quad$ The use of teaching learning resources and strategies e.g. relies and specimen, demonstration etc. for teaching will help pupils understand concepts better than teaching in abstract.

- $\quad$ Organizing fieldtrips for the students will help them recognize the benefits of learning BDT (Sewing)

- $\quad$ More time should be allotted to BDT ( Home Economics) in order to help students have hands on practice for a better understanding of the course

Majority of the students stated that,the government and school authorities should provide teaching and learning resources for BDT(Sewing).this confirms the earlier assumption made by the student that when the needed materials are not provided by the school Authorities to enhance learning it will lead to low performance. Daniel and Hobson (1985) stated that Home Economics teachers need both theoretical and practical resources when preparing for the class and most especially Clothing Textiles (Sewing). According to Blankenship and (1979) materials needed for teaching support activities that has been planned to help pupils achieve objectives. Kay (1971) also says materials needed for teaching are intended to help the teacher to teach more effectively or better still, which enables the pupils to learn more readily.

Majority of the respondents also stated that, parents should beable to the buy needed material for students to enhance the interest and good performance in BDT sewing. This is because when parents are not able to provide the needed materials for their kids the interest of that kid in the subject will be low. Since he or she does not take part in the lesson during practical lessons.

The effective use of instructional materials and strategies to make teaching and learning motivating to increase students' interest and performance was also raised by a majority of the respondents. According to Blankenship and Moerchern (1979) teaching and learning materials support activities that have been planned to help students achieve objective: Kay (1971: 37) also says "teaching aids are things which are intended to help the teacher to teach more effectively or better still, which enable the pupils to learn more readily".Farrant (1990) points out that since students learn best by doing and find more interest and enjoyment in activity, it is important to use the demonstration method in teaching Clothing and Textiles (Sewing). This method was developed and shaped by Dr. William Kilpatrick of the University of Columbia in U.S.A. to change the traditional classroom environment characterized by lack of interest. According to Talabi (2003) the demonstration method enables the teacher to display certain objects and actions in the class so as to teach a particular concept. He added that a good demonstration should proceed gradually and systematically so as to enable learners assimilate the concepts.

Most of the pupils stated that, when they go on field trips it will help develop interest in the subject. When pupils are exposed to career opportunities in Clothing and Textiles through field trips, it will help pupils to develop interest and get to know the different types of jobs involved and will also help pupils to have a wide variety of knowledge and information on various careers in clothing and textiles industry. Forson (1994) observed that, clothing and textiles related careers are seen by many as low status job as far as other careers are concerned. In spite of this misconception by many, if students are exposed to Clothing and Textiles careers through fieldtrips, they would get to know the importance of this beneficial subject (Sewing).

Sixty Eight percent (68\%) of the respondentsare of the view that, the time allotted for the subject is too small but when increased can enhance pupils interest in BDT(Sewing).Since this is a practical oriented course, enough time is needed for 
the effectiveness of its teaching and learning. Enough time will enable teachers demonstrate practice and also aid the students to have a hands-on experience in order to derive the full benefit of learning BDT(Sewing).

\section{Conclusion}

Wrong perception of BDT(Sewing) as a subject, bad attitudes of both teachers and students towards BDT (sewing), government, students and parent's inability to provide materials for learning BDT(Sewing) and less time allocation are some of the factors influencing poor performance of student in BDT(Sewing) and this can only be enhanced if there is a total change of the way everyone perceives Sewing as an academic discipline.

\section{Recommendation}

- Sensitization programs should be organized by the Ghana Home Economics Association on the importance of Clothing and Textiles (Sewing) to the individual, the nation and the world.

- School authorities should organize field trips for pupils to know the importance of BDT sewing is about.

- Teachers should use appropriate teaching and learning materials when teaching BDT sewing to make teaching and learning interesting.

- $\quad$ CRDD should allocate adequate time for BDT sewing.

- The government, school authorities and individual families should help provide the basic teaching learning resources for BDT (Sewing) to the pupils.

- Pupils should be given project works in BDT sewing to try their hands on after school.

\section{References}

i. Aiken,L. (2002). Attitudes and Related Psychosocial Constructs: Theories, Assessment, and ... retrieved from https:/ / books.google.com.gh/ books?isbn=1452267189 on 07-02-2018

ii. Akyeampong, A. K. (2002). Vocationalisation of secondary education in Ghana. Paper prepared for the Regional Vocatioal skills Development Review, Africa Region. Washington, DC: World Bank.

iii. Anamuah-Mensah, J. (2004). Vocational/ technical education for accelerated wealth creation: Critical issues facing the nation. Paper presented at the $56^{\text {th }}$ New Year School Conference organised by the Institute of Adult Education at University of Ghana on 30th December, 2004.

iv. Annoh,(2006).Modern approaches to researches in education administration for research students. Lecturer and Research fellow center for educational policy studies, university of Education, Winneba. Ghana: University press

v. Arubayi D.O (2003). Problems confronting the teaching of Clothing and Textiles in tertiary institutions. Journal of Educational Research and Development, 2(1): 53- 62. .

vi. Asare, K. B. \&Nti, S. K. (2014). Report of the President's committee on education reforms in Ghana. Accra, Ghana: Adwinsa Publications.

vii. Asare, K.B. (2009). Education: Training, retraining, and retaining teachers in Ghana (Part 1). Retrieved fromhttp:/ / www.modernghana.com/ news/ 211101/ 1/ education-training-retraining-and-retaining-teache.html.

viii. Blankenship.M.L and Moerchen, B.D (1979).Home Economic USA: Houghton Muffin Company.

ix. Budu-Smith, J. (2005). The need for Polytechnics to assert and create a niche for themselves among tertiary institutions in human resource development. Journal of Polytechnics in Ghana, 1(1).

x. $\quad$ Chavkin, L. (1993). Family impact on Education. American Educator, 1, 1-12. U.S.A: Houghton Muffin Company.

xi. Daniels, D, Hobson, U. (1985). Teaching skills work books. Honkong: Macmillan education Ltd..

xii. Decroly, O. (2009), retrieved on 3-5-2016 from www.ibe.unesco.org/ sites/ default/ files/ decrolye.pdf

xiii. Fomadi,R. (2008). Clothing and Textile and not for the less intelligent students. Retrieved from www.mordern.com

xiv. / news

xv. Farrant.J.S. (2004). Principles and practice of teacher education. London: Longman group Ltd.

xvi. Forster, P. (2014). Clothing \& Textiles. Accra: Winmat Publishers Ltd.

xvii. Italian Republic-Country overview (2015). Retrieved, September, 8, 2016 from www.nationsencyclopedia.com

xviii. Ghana Education Service (2007). Teaching Svllahus for Basic Design and Technology. Accra: Curriculum and Research Development Divi:

xix. Hall,O.A.\& Paulucci, B. (1970). Teaching Hor $\quad$ s (2nd Ed).U.S.A: Wiley and sons inc.

xx. $\quad$ Kay, N. C (1971). Practical Teaching:Ibadani: Evans Brothers Limited

xxi. Mankoe, J.O (2002). Educational administration and management in Ghana. Accra: programme star printing press

xxii. Mberengwa L (2004). Curriculum change in Home Economics education at Gweru Teachers College, Zimbabwe, 1975 1995 Journal of Family and Consumer Sciences Education, 22(2): 17-23.

xxiii. Ministry of Education (2010). Teaching syllabus for Clothing and Textiles. Accra: Curriculum Research and Development.

xxiv. Ministry of Education (2007). Teaching syllabus for basic design and technology (Junior High school1-3).Accra: Curriculum Research and Development Division.

xxv. Ministry of Education (2002). The Educational Reform Programme: Policy Guidelines on Education. Accra: MOE. 
xxvi. Schneider, F. W., Gruman, J. A., \& Coutts, L. M. (2012). Applied social psychology. (2nd ed.). Thousand Oaks, California: SAGE Publications, Inc.

xxvii. Talabi, J.K (2003). Educational technology: Methodist tools and techniques for effective teaching. Accra: university press.

xxviii. Walberg.M (1984).Education and the family. Sociology of Education New York: Glance publishing company

xxix. Waudo J (1993). Home Economics Education in Africa: Reflections and Prospects. Canadian Home Economics Journal, 43(4) 